\title{
THE EFFECT OF FINANCIAL PERFORMANCE ON STOCK PRICE AT PHARMACEUTICAL SUB- SECTOR COMPANY LISTED IN INDONESIA STOCK EXCHANGE
}

\author{
Edhi Asmirantho'), Oktiviani Kusumah Somantri ${ }^{2)}$ \\ Faculty of Economics, Pakuan University, Indonesia. \\ Email: rantho.bs@gmail.com ${ }^{1)}$ dan oktivianikusumah@gmail.com ${ }^{2)}$
}

\begin{abstract}
This study aims to determine the effect of likuidity, solvency, activity, profitability and market with Current Ratio (CR), Debt to Equity Ratio (DER), Total Assets Turnover (TATO), Return on Equity (ROE), and Earnings per Share(EPS), as indicators, of the pharmaceutical company listed in Indonesia Stock Exchange during the period 2012-2016 to stock price. The type of research is explanatory survey verification and research technique used is inferential statistic. In addition the analytical method used in this research is regression analysis of panel data, namely, $t$ test, $F$ test, and classical assumption of normality, multicollinearity, heteroscedasticity and autocorrelation tests with E-Views 9. The results showed that in partial EPS significantly effects stock price, while CR, ROE, DER, and TATO had not significantly effect the stock price. Adjusted $R$ square value was 0,5040 which showed that CR, DER, TATO, ROE, and EPS influenced the dependent variable by $50,40 \%$, while the remaining $49,6 \%$ was influenced by other variables. It can be conluded that in sub sector pharmaceutical, investors were more concerned about the company's EPS instead of other variables. On the other hand, investors simultaneously concerned the CR, DER, TATO, ROE, and EPS in their investment decision and also other variables which were not included in this research.
\end{abstract}

Keywords: Current Ratio, Debt to Equity Ratio, Total Assets Turnover, Return on Equity, Earning Per Share, Stock Price

\section{PRELIMINARY}

The Indonesian economy is seen to continue to grow. World Bank (World Bank) also projected economic growth in Indonesia in 2017 is 5.2\%, bigger than last year at $5.02 \%$. Economic development is one of them is supported by the development of various sectors in Indonesia (detikfinance.com).

The Goods and Consumer Industry sector managed to become the strongest stock market index in early 2017. The Indonesia Stock Exchange (BEI) noted that the Goods and Consumer Sector Index rose up to $3.02 \%$, while the strengthening of the Goods and Consumption Sector was influenced by market participants by buying shares in various Sub Sector of Industrial Goods and Consumption one of them is Sub Sector Pharmacy (cnnindoneisa.com).
Sub Sector Pharmacy is one of the industries that play an important role in health sector as a provider of drugs needed by the community.

The performance of the Indonesian pharmaceutical industry has recorded significant growth. In terms of total domestic pharmaceutical market value recorded higher than Malaysia and Singapore. The existence of government regulations and health assistance projects from international institutions has also contributed significantly to the development of the pharmaceutical industry so that the Indonesian pharmaceutical industry grew to reach Rp.37 trillion (kemenperin.go.id).

In addition, Indonesia's pharmaceutical market growth is the fastest in Asia with an average growth of $20.6 \%$ per year since 2011 2016. Based on investment realization data 
from the Investment Coordinating Board (BKPM) the Domestic Investment (PMDN) is dominated by the pharmaceutical industry, basic chemicals and chemical goods worth Rp12.9 trillion (mediaindonesia.com).

It shows how big market potential for big pharmaceutical sub sector companies in Indonesia is to encourage investors to invest in capital market in Pharmaceutical Sub-sector. And with the good development in Pharmaceutical Sub Sector in accordance with the above reporting, it should have a good impact also the assessment of the investors towards Pharmaceutical Sub Sector so that the stock price in Pharmaceutical Sub Sector companies can increase due to the many interest from the investors.

According to Haymans $(2008,95)$ "Stock prices can be assessed or analyzed by two approaches, namely technical and fundamental. In this study, to determine the true value of shares using fundamental analysis". Meanwhile, Shim \& Siegel (2007, 202) stated that fundamental analysis evaluates a stock by analyzing the company's financial statements. Financial statement analysis provides you with much of the data you require to forecast earnings, dividends, and selling price.

Based on the theory, fundamental analysis evaluates the stock by analyzing the company's financial statements. Financial statement analysis provides much needed data to predict earnings, dividends, and selling prices. Fundamental analysis looks at the position of the company's financial statements relating to the company's financial performance.

According to Asmirantho $(2013,270)$ financial performance is an achievement achieved by the company in a certain period to see how far a company has been implementing with the rules of financial implementation properly and correctly. This can be seen in the financial statements consisting of balance sheets, income statements, changes in capital and cash flow statements. According to Tracy $(2012,6)$ "Financial ratio are divided into JIAFE (Jurnal IImiah Akuntansi Fakultas Ekonomi) Volume 3 No. 2 Tahun 2017, Hal. 94-107 five types: liquidity, activity, debt, profitabiity, and market ratios". Based on this theory, in this research the researcher use the 5 ratio is Liquidity Ratio as measured by Current Ratio, Solvability Ratio is measured by Debt To Equity Ratio, Activity Ratio with Total Assets Turn Over, Profitability Ratio with Return On Equity, and Ratio Value of The market which is measured using Earning Per Share. The first ratio is expected to affect the stock price of Current Ratio (CR) which is an indicator of the Liquidity Ratio.

According to Brigham \& Houston (2010, 134) Current Ratio is calculated by dividing current assets with current liabilities, this ratio shows the extent to which current liabilities are covered by assets that are expected to be converted into cash in the near future. The higher the ratio, the greater the company's ability to pay bills. This may affect the interest of investors to invest in the company, consequently the company's stock price will increase. Therefore CR moves in the direction of stock prices.

The formula of Current Ratio (CR) is as follows:

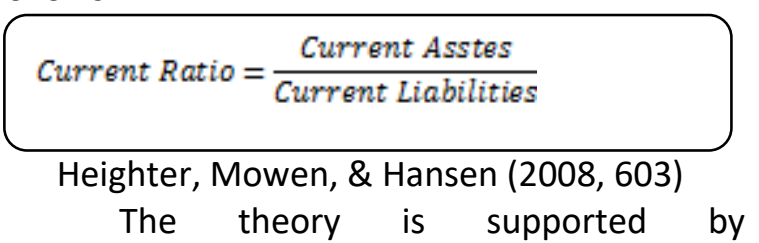

Bagharzadeh \& Mahboobeh (2013), Reynard \& Lana (2013) researchs which stated that the Current Ratio partially have a positive and significant effect on stock prices. The research from Sajiyah (2016) states Current Ratio has a negative effect on stock prices. Meanwhile, according to Manopo \& Jan (2017) partially Current Ratio has no effect and positive to stock price. The next ratio in this study is expected to affect the stock price of Debt To Equity Ratio (DER) which is an indicator of Solvency Ratio.

According to Van Horne \& Wachowizc $(2009,209)$ "when the value of Debt To Equity Ratio is low then the higher the level of corporate funding provided by the shareholders and the greater the protection for creditors". While Khan \& Jain $(2012,94)$ stated if the debt 
to equity ratio is high, the owners are putting up relatively less money of their own. It is a danger signal for the creditor. If the project should fail financially, the creditors would lose heavily.

Based on the above theory, if the debt to equity ratio is high, the owners make relatively little money. This is a danger signal for creditors. On the contrary, when the low DER value will increase the positive response of the market and the better the company's ability to pay long-term liabilities because the risks arising from the use of funding derived from debt will be reduced, thus affecting the increase in stock prices. Therefore, DER moves in opposite direction with stock prices.

The formula of Debt to Equity Ratio (DER) is as follows:

$$
\text { Debt to Equity Ratio }=\frac{\text { Total Liabilities }}{\text { Total Equity }}
$$

Godwin \& Alderman $(2010,261)$

The theory is supported by research by Asmirantho and Yuliawati (2015), Frendy, Tomy, and Mangantar (2015), Putu and Suaryana (2013) and Tan, Syarif and Ariza (2014) stating that DERs have a negative and significant effect on stock prices. And according to research of Murniati (2016) Debt to Equity Ratio have positive and significant effect to stock price. There are also Komala \& Nugroho (2013), Sudarsono \& Sudiyatno (2016) and Johannes \& Arisandi (2013) studies which show that DER variable has no effect and positive on stock price.

The next ratio in this study expected to affect the stock price is Total Assets Turn Over (TATO) which is an indicator of the Activity Ratio. According to Baginski, Wahlen, et al (2017, 230) Total Assets Turn Over captures how efficiently the firm utilizes assets to generate revenues. Higher revenues generated with a given level of assets indicates more efficient use of those assets.

Total asset turnover ratio measures how efficiently a company uses its assets to generate revenue. The more efficient use of all company assets to support sales activities, it will affect the increase in corporate income. So the higher the value of TATO will attract investors so that it causes a rise in stock prices. Therefore TATO moves in line with stock prices.

The formula of TATO is as follows:

$$
\text { Total Assets Tumover }=\frac{\text { Net Sales }}{\text { Total Aset }}
$$

Brigham \& Houston $(2010,139)$

The theory is supported by previous research from Adipalguna and Gede (2016) which states that TATO has a positive and significant impact on stock prices. While Hutapea, Saerang, and Tulung (2017) states that TATO has a negative effect on stock prices.

The next ratio in this study expected to affect the stock price is Return On Equity (ROE) which is an indicator of Profitability Ratio. According to Brigham and Houston $(2010,149)$ "The ratio of net income to ordinary equity is a ratio that measures the rate of return on ordinary shareholder investment."

According to McLean $(2003,74)$ "The Return on Equity Ratio also measure the organization's ability to pay a return to its equity holders and is defined as net income dividend by owners equity."

Based on the above theory, Return on Equity measures the ability of firms to provide returns for shareholders and is defined as dividends in net income over equity holdings. When a company has a good ability to provide returns on stock ownership, it indirectly will make investors have more confidence in the company. This will affect investors to invest so that stocks are in great demand and the company's stock price will increase. Therefore ROE moves in the direction of stock prices. is as follows:

The formula of Return On Equity (ROE)

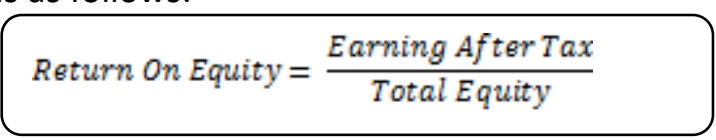

Brigham \& Houston $(2010,150)$ 
The theory is supported by previous research by Haque and Faruquee (2013), Murniati (2016), Tan, Syarif, and Ariza (2014), and Asnita (2013) which states that ROE has a positive and significant effect on stock prices. Meanwhile, according to research conducted by Komala \& Nugroho (2013), Indrawati \& Suprihadi (2016) states that ROE has a negative and significant effect on stock prices. And according to research by Talamati \& Pangemanan (2015), and Artha, Sasongko, et al (2014) states that ROE has no effect and positive on stock prices.

The next ratio in this study is expected to affect the stock price of Earning Per Share (EPS) which is an indicator of the ratio of Market Value. Accordding to Mehta (2016, 437) the performance and prospects of the company are affected by earning per share. If earning per share increases, there is a possibility that the company may pay more dividend or issues bonus share.

Based on the theory, the performance and prospect of the company is influenced by Earning Per Share. If the value of Earning Per Share increases, it is possible that the company can pay more dividends or issue bonus shares. With greater shareholder profits it will attract investors to invest so as to drive stock prices up. Therefore EPS moves in the direction of stock prices.

The formula of Earning Per Share (EPS) is as follows:

$$
\text { Earning PerShar }=\frac{\text { EAT }(\text { Earning After Tax })}{\text { Number of Shares }}
$$

Brigham \& Houston $(2010,150)$

Therefore, the high EPS value will make the stock price higher because the better the company in the eyes of investors. The theory is supported by previous research of Kodithuwakku (2016), Wati (2015), Gupta (2016), and Prabath (2014) stating that EPS has a positive and significant effect on stock prices. Meanwhile, according to research of Artha, Sasongko, et al (2014) which shows that Earning Per Share have no effect and positive to stock price.

\section{RESEARCH HYPOTHESES}

Based on the above framework, the research tries to formulate the hypothesis as follows:

H1: Current Ratio (CR) has a positive effect on Stock Price.

H2: Debt to Equity Ratio (DER) has a negative effect on Stock Price.

H3: Total Assets Turnover (TATO) has a positive effect on Stock Price.

H4: Return On Equity (ROE) has a positive effect on Stock Price.

H5: Earning Per Share (EPS) has a positive effect on Stock Price.

H6: Current Ratio, Debt to Equity Ratio, Total Assets Turnover, Return on Equity, and Earning Per Share simultaneously affect the Stock Price.

\section{OBJECT AND RESEARCH METHODS Types of research}

Type of research used in this research is verifikatif research with Explanatory Survey method. The objects in this study are the variables that serve as the theme or title of research. In this research, there are two variables that are independent variable $(X$ variable), with indicators of Current Ratio (X1), Debt to Equity Ratio (X2), Total Assets Turnover (X3), Return on Equity (X4), Earning Per Share (X5). While the dependent variable (variable $Y$ ) in this study is Stock Price.

\section{Unit of Analysis}

In this study the unit of analysis used is a company that is Sub Sector Pharmaceutical (Industry Consumer Goods) listed in the Indonesia Stock Exchange.

\section{Research sites}

The location of the study is where the variables of the study are analyzed such as organization / company / institution or certain area. In this research, the research location is 8 companies from 10 companies of Pharmaceutical Sub-sector (Industry of Consumer Goods) listed on Indonesia Stock Exchange by taking data on the official website of Indonesia Stock Exchange. 


\section{Types and Sources of Research Data}

The type of data studied is quantitative data, i.e. data on numbers, levels, comparisons, and volumes in the form of numbers. Sources of research data used is secondary data. In this study data sources obtained by researchers from the Indonesia Stock Exchange through the official website of Indonesia Stock Exchange: www.idx.co.id, duniainvestasi.com, and sahamok.com.

\section{Sampling Method}

In this research sampling method used is purposive sampling method that is done by choosing subject based on certain criteria. The criteria are adjusted to the problems studied, from 10 companies to produce 8 sample data of Pharmaceutical Sub sector (Industry of Goods and Consumption) listed in Indonesia Stock Exchange are as follows:

1) Pharmaceutical Sub-Sector Companies listed on the Indonesia Stock Exchange,

2) Pharmaceutical Sub Sector Companies that have complete financial data in the period 2012-2016,

3) Pharmaceutical Sub-Sector Companies with an IPO of more than 5 years,

4) Pharmaceutical Sub-Sector Companies that did not experience delisting during the observation period,

\section{RESEARCH RESULT}

Descriptive Statistics of Research Variables
5) Pharmaceutical Sub-Sector Companies that do not have negative equity totals during the observation period.

\section{Panel Data Regression Test}

In this research, the regression equation of panel data with 5 independent variables is as follows:

$Y_{\text {it }}=\alpha+\beta_{1} X_{1 i t}+\beta_{2} X_{2 i t}+\beta_{3} X_{3 i t}+\beta_{4} X_{4 i t}+\beta_{5} X_{\text {5it }}$

Harga Saham $=\alpha+\beta_{1}$ CR $+\beta_{2}$ DER $+\beta_{3}$ TATO +

$$
\beta_{4} R O E+\beta_{5} \text { EPS }
$$

Information :

$Y_{i t}$ :Dependent variable / dependent (stock price)

$\alpha$ : The constant, ie the value of Yit if $X 1, X 2$, $\mathrm{X} 3, \mathrm{X} 4$, and $\mathrm{X} 5=0 \mathrm{i}$ : Entitas ke-i

$\mathrm{t}$ : The t period

$\mathrm{X}_{1}$ : Current Ratio (CR)

$\mathrm{X}_{2}$ : Debt to Equity Ratio (DER)

$\mathrm{X}_{3}$ : Total Assets Turnover (TATO)

$\mathrm{X}_{4}$ : Return On Equity (ROE)

$X_{5}$ : Earning Per Share (EPS)

$\beta_{1-} \beta_{5}$ : Regression coefficient, that is value increase or decrease of variable of Yit based on variable $\mathrm{X} 1, \mathrm{X} 2, \mathrm{X} 3, \mathrm{X} 4$, and X5 
Table 1

Results Descriptive Statistics Analysis

Date:02/19/18 Time: 11:42

Sample: 20122016

\begin{tabular}{lcccccr}
\hline \hline & HS & CR & DER & TATO & ROE & EPS \\
\hline \hline Mean & 54165.02 & 3.874255 & 0.511250 & 1.379705 & 0.288648 & 2520.735 \\
Median & 1720.000 & 2.985600 & 0.390850 & 1.293900 & 0.171100 & 59.41000 \\
Maximum & 413500.0 & 30.92690 & 1.605700 & 3.730800 & 1.158800 & 16613.44 \\
Minimum & 112.0000 & 1.183200 & 0.026600 & 0.144800 & -0.091800 & -17.50000 \\
Std. Dev. & 113318.7 & 4.574290 & 0.358416 & 0.629760 & 0.320146 & 5204.325 \\
Skewness & 1.941106 & 5.337889 & 1.612392 & 1.658547 & 1.501727 & 1.877885 \\
Kurtosis & 5.361920 & 32.19357 & 5.256312 & 7.002271 & 4.141630 & 4.893249 \\
& & & & & & \\
Jarque-Bera & 34.41706 & 1610.395 & 25.81695 & 45.03548 & 17.20677 & 29.48368 \\
Probability & 0.000000 & 0.000000 & 0.000002 & 0.000000 & 0.000183 & 0.000000 \\
& & & & & & \\
Sum & 2166601. & 154.9702 & 20.45000 & 55.18820 & 11.54590 & 100829.4 \\
Sum Sq. Dev. & $5.01 \mathrm{E}+11$ & 816.0409 & 5.010013 & 15.46732 & 3.997233 & $1.06 \mathrm{E}+09$
\end{tabular}

Observations

40

40

40

40

40

40

(Source: Processed by E-Views 9)

Based on table 1 , shows that the amount of data in this study is as many as 40 samples. Based on the calculation results for the period 2012-2016. The independent variables used in this research are CR (X1), DER (X2), TATO (X3), ROE (X4) and EPS (X5). And Independent Variables of Stock Price (Y). Of 40 stock price data, the lowest value (minimum) of 112 and the highest (maximum) of 413500 . While the average (mean) of 54165 with the standard deviation 1133318.7 .

In the variable Current Ratio (CR) shows the lowest (minimum) of 1.18 and the maximum (maximum) of 30.92. While the average (mean) of 3.87 with a standard deviation of 4.57. In the Debt to Equity Ratio (DER) variable the lowest (minimum) value is 0.0266 and the maximum (maximum) is 1.6057. While the average of 0.5112 with a standard deviation of 0.3584 . In the Total Assets Turn Over (TATO) variable the lowest (minimum) value is 0.1448 and the highest (maximum) is 3.3730 . While the average of 1.3797 with a standard deviation of 0.6297 . On Return On Equity (ROE) the lowest value (minimum) of -0.0918 and the highest (maximum) of 1.1588. While the average of 0.2886 with a standard deviation of 0.3201 . In Earning Per Share (EPS) the lowest value (minimum) of $-17,500$ and the maximum (maximum) of 16613.44. While the average of 2520.735 with a standard deviation of 5204.325 .

\section{Panel Data Analysis Results}

To choose which model is best for this research, panel data estimation technique is performed. Panel data estimation technique used in this research is to choose between model of common effect, fixed effect or random effect. To determine the exact model between the common effect model and fixed effect is done by using Chow Test. If the probability value for the cross section $\mathrm{F}>0.05$ then the selected model is the common effect, but if the probability value for cross section $F$ $<0.05$ then the selected model is fixed effect. Here are the Chow Test results:

Table 2

Chow Test Results

Redundant Fixed Effects Tests

Equation: Untitled

Test cross-section fixed effects

\begin{tabular}{lcrr}
\hline \hline Effects Test & Statistic & d.f. & Prob. \\
\hline \hline Cross-section F & 12.344188 & $(7,27)$ & 0.0000 \\
Cross-section Chi-square & 57.406667 & 7 & 0.0000 \\
\hline \hline
\end{tabular}

(Source: Processed by E-Views 9) 
Based on table 2, it shows that the probability value for cross section $F<0.05$ is 0.000 . So for Test Chow can be concluded that the selected model is fixed effect. Furthermore, to determine the exact model between random effect model or fixed effect is done by using Hausman Test. If the probability value for a random cross section $>0.05$, then the selected model is a random effect. But if the probability value for random cross section $<0.05$, then the selected model is fixed effect. The following test results hausman:

Table 3

Hausman Test

Results

Correlated Random Effects - Hausman Test

Equation: Untitled

Test cross-section random effects

\begin{tabular}{lrrr}
\hline \hline Test Summary & Chi-Sq. Statistic & Chi-Sq. d.f. & Prob. \\
\hline \hline Cross-section random & 4.731063 & 5 & 0.4496 \\
\hline \hline
\end{tabular}

(Source: Processed by E-Views 9)

Based on table 3, it shows that the probability value for cross section $\mathrm{F}>0.05$ is 0.4496 . So for Hausman Test can be concluded that the selected model is random effect.

Furthermore, to determine the exact model between the model of common effect or random effect is done by using Lagrange Multiplier Test. If the probability value for the Breusch-Pagan cross section is $>0.05$, then the selected model is the common effect. But if

Table 5

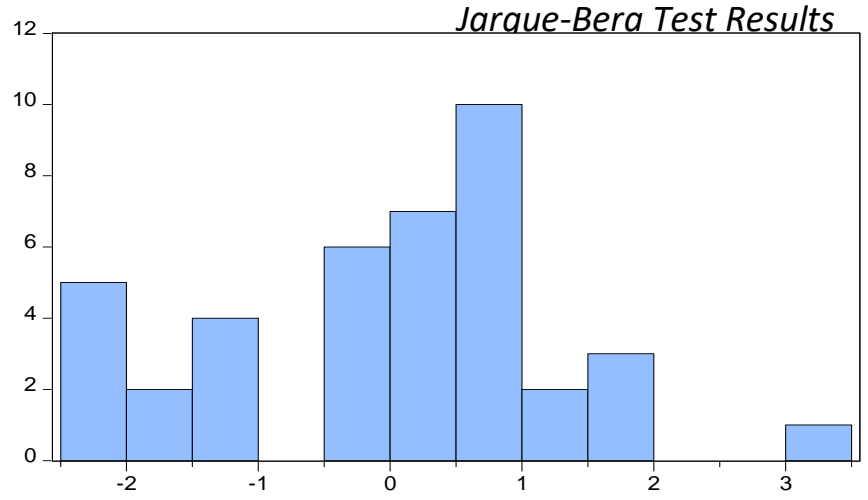

the probability value for the Breusch-Pagan cross section $<0.05$, then the selected model is a random effect. The following test results Lagrange Multiplier:

Table 4

Lagrange Multiplier Test

Results

Lagrange Multiplier Tests for Random Effects

Null hypotheses: No effects

Alternative hypotheses: Two-sided (Breusch-Pagan) and one-sided (all others) alternatives

\begin{tabular}{lcll}
\hline \hline & \multicolumn{3}{c}{ Test Hypothesis } \\
& Cross-section & \multicolumn{1}{c}{ Time } & \multicolumn{1}{c}{ Both } \\
\hline \hline \multirow{2}{*}{ Breusch-Pagan } & 24.61176 & $\begin{array}{l}2.598673 \\
\text { (0.1070) }\end{array}$ & $\begin{array}{l}27.21044 \\
(0.0000)\end{array}$
\end{tabular}

(Source: Processed by E-Views 9)

Based on table 4 , it shows that the probability value for the Breusch-Pagan cross section $<0.05$ is 0.0000 . So it can be concluded that the model used is Random Effect.

\section{Normality test}

The normality test on the regression model is used to test whether the residual value generated from the regression is normally distributed or not. A good regression model is one that has a normally distributed residual value. The distribution is said to be normal if the Jarque-Bera value is not significant (smaller than two) and the probability value> 0.05 . The results of normality test processing and Jarque-Bera numbers as follows:

(Source: Processed by E-Views 9)

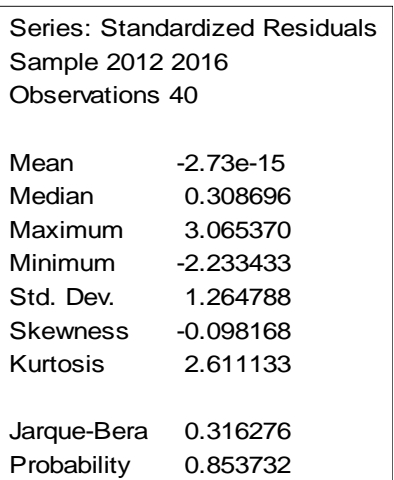

Probability $\quad 0.853732$ 
Based on table 5 it can be seen that the value of Jarque-Bera is smaller than two that is equal to 0.316276 and probability or probability value of 0.853732 where greater than 0.05 . So it can be concluded that the regression model is normally distributed.

\section{Autocorrelation Test}

Table 6

Durbin-Watson Test Result

\begin{tabular}{llll}
- & \multicolumn{3}{c}{ Weighted Statistics } \\
\hline \hline R-squared & 0.567625 & Mean dependent var & 1.752914 \\
Adjusted R-squared & 0.504041 & S.D. dependent var & 0.898009 \\
S.E. of regression & 0.632417 & Sum squared resid & 13.59836 \\
F-statistic & 8.927101 & Durbin-Watson stat & -1.907304 \\
Prob(F-statistic) & 0.000017 & & \\
\hline \hline
\end{tabular}

(Source: Processed by E-Views 9)

Based on table 6, it can be seen that the DW number shows the result of 1.907304. By looking at the DW table, with the number of variables $5(k=5)$ and the number of observations $=40(n=40)$ then obtained DU value of 1.7859. Thus, 4-DU $=2.2141$. So DU $<$ DW $<4-D U$ or $1.7859<1.907304<2.2141$. because the DW value is between DU and 4DU then it means no autocorrelation occurs.

\section{Heteroscedasticity Test}

Table 7

Glejser Test Results

Dependent Variable: ABS(RESID01)

Method: Panel EGLS (Cross-section random effects)

Date: 01/28/18 Time: 13:44

Sample: 20122016

Periods included: 5

Cross-sections included: 8

Total panel (balanced) observations: 40

Swamy and Arora estimator of component variances

\begin{tabular}{crrrr}
\hline \hline Variable & Coefficient & Std. Error & t-Statistic & Prob. \\
\hline \hline CR & -0.006009 & 0.017912 & -0.335478 & 0.7393 \\
DER & 0.217005 & 0.478390 & 0.453615 & 0.6530 \\
TATO & -0.086519 & 0.241363 & -0.358462 & 0.7222 \\
ROE & -0.294739 & 0.283033 & -1.041357 & 0.3051 \\
EPS & $3.87 \mathrm{E}-05$ & $4.45 \mathrm{E}-05$ & 0.868888 & 0.3910 \\
C & 1.030947 & 0.587513 & 1.754764 & 0.0883 \\
\hline \hline
\end{tabular}

(Source: Processed by E-Views 9)

Based on table 7 , it can be seen that the probability value for the five independent variables namely Current Ratio of 0.7393 , Debt to Equity Ratio of 0.6530 , Total Asset Turnover of 0.7222 , Return On Equity of 0.305 and Earning Per Share of 0,3910 . Thus it can be concluded that there is no problem of heterokedastisitas on regression model.

\section{Multicolinearity Test}


Table 8

Multicollinearity Test Results

\begin{tabular}{crrrrr} 
& CR & DER & \multicolumn{1}{c}{ TATO } & \multicolumn{1}{c}{ ROE } & \multicolumn{1}{c}{ EPS } \\
\hline \hline CR & 1.000000 & -0.281305 & 0.166737 & 0.032532 & 0.130282 \\
DER & -0.281305 & 1.000000 & -0.369956 & -0.248570 & -0.376763 \\
TATO & 0.166737 & -0.369956 & 1.000000 & 0.080083 & 0.775659 \\
ROE & 0.032532 & -0.248570 & 0.080083 & 1.000000 & 0.294779 \\
EPS & 0.130282 & -0.376763 & 0.775659 & 0.294779 & 1.000000
\end{tabular}

(Source: Processed by E-Views 9)

Based on table 8, it can be seen that the value of correlation coefficient between independent variables i.e. CR and DER of $0.281305, C R$ and TATO of 0.166737, CR and ROE of 0.032532 , CR and EPS of 0.130282 , DER and TATO of -0.369958, DER and ROE of 0.248570 , DER and EPS of -0.376763 , TATO and
ROE of 0.080083 , TATO and EPS of 0.775659 , ROE and EPS of 0.294779. So it can be concluded that the regression model does not occur multicollinearity problems because all values of correlation coefficient between independent variables worth less than 0.8 .

\section{Regression Result of PaneL Data, T test, F test}

Table 9

Panel Data Regression Test Results

\begin{tabular}{|c|c|c|c|c|}
\hline \multicolumn{5}{|c|}{$\begin{array}{l}\text { Dependent Variable: LOGHS } \\
\text { Method: Panel EGLS (Cross-section random effects) } \\
\text { Date: } 02 / 12 / 18 \text { Time: } 18: 22 \\
\text { Sample: } 20122016 \\
\text { Periods included: } 5 \\
\text { Cross-sections included: } 8 \\
\text { Total panel (balanced) observations: } 40 \\
\text { Swamy and Arora estimator of component variances }\end{array}$} \\
\hline Variable & Coefficient & Std. Error & t-Statistic & Prob. \\
\hline CR & 0.023441 & 0.025196 & 0.930341 & 0.3588 \\
\hline DER & 0.543079 & 0.681887 & 0.796435 & 0.4313 \\
\hline TATO & -0.012021 & 0.341678 & -0.035182 & 0.9721 \\
\hline ROE & 0.419515 & 0.400064 & 1.048620 & 0.3018 \\
\hline EPS & 0.000419 & $6.44 \mathrm{E}-05$ & 6.501021 & 0.0000 \\
\hline $\mathrm{C}$ & 6.473012 & 0.850464 & 7.611150 & 0.0000 \\
\hline \multicolumn{5}{|c|}{ Effects Specification } \\
\hline & & & S.D. & Rho \\
\hline $\begin{array}{l}\text { Cross-section random } \\
\text { Idiosyncratic random }\end{array}$ & & & 1.264597 & $\begin{array}{l}0.7987 \\
0.2013\end{array}$ \\
\hline \multicolumn{5}{|c|}{ Weighted Statistics } \\
\hline R-squared & 0.567625 & \multirow{5}{*}{\multicolumn{2}{|c|}{$\begin{array}{l}\text { Mean dependent var } \\
\text { S.D. dependent var } \\
\text { Sum squared resid } \\
\text { Durbin-Watson stat }\end{array}$}} & 1.752914 \\
\hline Adjusted R-squared & 0.504041 & & & 0.898009 \\
\hline S.E. of regression & 0.632417 & & & 13.59836 \\
\hline F-statistic & 8.927101 & & & 1.907304 \\
\hline Prob(F-statistic) & 0.000017 & & & \\
\hline \multicolumn{5}{|c|}{ Unweighted Statistics } \\
\hline & 0.743078 & \multirow{2}{*}{\multicolumn{2}{|c|}{$\begin{array}{l}\text { Mean dependent var } \\
\text { Durbin-Watson stat }\end{array}$}} & \\
\hline Sum squared resid & 62.38788 & & & 0.384616 \\
\hline
\end{tabular}

(Source: Processed by E-Views 9)

Table 20 describes the model summary Ratio, Debt to Equity Ratio, Total Assets Turn of the panel data regression test results and Over, Return On Equity, and Earning Per Share the following interpretation of the results of value of 0 , then the stock price increased by the panel data regression model above. 6.4730 .

Constant value of 6.4730 means if the Current 
The value of regression coefficient variable Current Ratio (CR) is positive value of 0.0234 means that each increase of Current Ratio of one unit, then the Share Price will increase by 0.0234 with the assumption of other independent variables fixed value.

The value of regression coefficient of Debt to Equity Ratio (DER) is positive that is equal to 0,5430 means every increase of Debt to Equity Ratio equal to one unit, hence share price will experience increase equal to 0,5430 assuming other independent variable value remain the same.

The value of regression coefficient of Total Assets Turn Over (TATO) is negative value that is equal to $-0,0120$ means that each increase of Total Assets Turn Over by one unit, then share price will decrease equal to $-0,0120$ assuming other independent variable is fixed value.

Value of regression coefficient of Return On Equity (ROE) is positive value that is equal to 0,4195 which means every increase in Return On Equity equal to one unit, hence share price will experience increase equal to 0,4195 with assumption other independent variable value remain.

The value of regression coefficient of Earning Per Share (EPS), positive value is 0.0004 means that every increase of Earning Per Share (EPS), equal to one unit, then share price will experience increase by 0.0004 with sumsi other independent variable fixed value.

The coefficient of determination ( $R$ Square) is 0.567625 . This result shows that the variation of stock price can be explained by the value of Current Ratio (CR), Debt to Equity Ratio (DER), Total Asset Turn Over (TATO), Return on Equity (ROE), and Earning Per Share (EPS) of $56.7625 \%$. While the rest of $43,2375 \%$ is explained by other variables not included in this model.

Adjusted R Square of 0,504041 shows contribution of variable influence of Current Ratio (CR), Debt to Equity Ratio (DER), Total Asset Turn Over (TATO), Return on Equity (ROE), and Earning Per Share (EPS) Hargasaham of $50.40 \%$.Adjusted R Square is used because the variables in this study are more than one variable.

\section{t Test}

The $\mathrm{t}$ test is conducted to find out whether partially variable of Current Ratio (CR), Debt to Equity Ratio (DER), Total Assets Turnover (TATO), Return on Equity (ROE), and Earning Per Share (EPS) have influence significantly or not against stock price.

\section{a) Current Ratio (CR)}

Based on table 20, obtained the estimation result of Current Ratio with positive regression coefficient value equal to 0,023441 and $t$ test probability value bigger than specified significance level that is $5 \%(0,3588>$ $0,05)$. It shows that the Current Ratio (CR) does not affect the stock price of Pharmaceutical sub-companies listed on the BEI period 20122016. So it can be concluded that $\mathrm{H} 1$ is rejected.

\section{b) Debt to Equity Ratio (DER)}

Based on table 20 also, obtained the estimation results of Debt to Equity Ratio with positive regression coefficient value of 0.543079 and the probability value of $t$ test is greater than the specified significant level of $5 \%(0.0413>0.05)$. It shows that Debt to Equity Ratio (DER) does not affect the stock price of Pharmaceutical sub-sector listed on BEI period 2012-2016. So it can be concluded that H2 is rejected.

\section{c) Total Assets Turnover (TATO)}

Total Assets Turnover found to have negative regression coefficient value which is 0.012021 and the probability value of $t$ test is greater than the specified significance level that is $5 \%(0,9721>0,05)$. This shows that Total Assets Turnover (TATO) does not affect the stock price of Pharmaceutical sub-companies listed on the BEl period 2012-2016. So it can be concluded that $\mathrm{H} 3$ is rejected. 


\section{d) Return On Equity (ROE)}

Return On Equity showed positive regression coefficient value of 0,419515 and probability value of $t$ test bigger than specified significance level that is $5 \%(0,3018>0,05)$. It shows that Return On Equity (ROE) does not affect the stock price of Pharmaceutical subsector listed on the BEl period 2012-2016. So it can be concluded that $\mathrm{H} 4$ is rejected.

\section{e) Earning Per Share (EPS)}

Earning Per Share variable found to have positive regression coefficient value 0.000419 and the probability value of $t$ test is smaller than the specified significance level that is $5 \%(0,0000<0,05)$. It shows that Earning Per Share (EPS) has a positive and significant effect on stock prices of Pharmaceutical subcompanies listed on the BEI period 2012-2016. So it can be concluded that $\mathrm{H} 5$ is accepted.

\section{F Test}

The $\mathrm{F}$ test is performed to determine whether the independent variable $(\mathrm{X})$ : Current Ratio (CR), Debt to Equity Ratio (DER), Total Assets Turnover (TATO), Return on Equity (ROE), and Earning Per Share (EPS) influential significantly to the dependent variable $(\mathrm{Y})$ : share price with a significance level of 0.05 . The following hypothesis testing is performed simultaneously based on the output of E-views 9:

Based on the output table 20, the results of the $F$ test or simultaneous coefficient test simultaneously (together) above shows that F-statistic of 8.9271 with significance below 0.05 . It can be concluded that together with Current Ratio, Debt to Equity Ratio, Total Assets Turnover, Return on Equity, and Earning Per Share have significant effect on stock price. So it can be concluded that $\mathrm{H} 6$ is accepted.

\section{CONCLUSIONS AND SUGGESTIONS}

\section{Conclusions}

1) Test results show that Current Ratio has a coefficient of 0.023441 and significance of $0.3588>0.05$. The results obtained show that $C R$ is not influential and positive on the stock price of Sub-Pharmaceutical companies listed on the BEl period 20122016, so it can be concluded that the hypothesis that the Current Ratio positive effect on stock prices rejected.

2) The test results show that Debt to Equity Ratio has a coefficient value of 0.543079 and the significance of $0.0413>0.05$. The results obtained show that DER has no effect and positive on stock price of Pharmaceutical Sub-Sector listed on BEI period 2012-2016, so it can be concluded that the hypothesis stating that Debt to Equity Ratio negatively affect the stock price is rejected.

3) Test results show that Total Assets Turnover has a coefficient of -0.012021 and significance of $0.9721>0.05$. The results obtained show TATO has no effect and negatively on the stock price of Pharmaceutical Sub-Sector companies listed on the IDX period 2012-2016, so it can be concluded that the hypothesis that the Total Assets Turnover positive effect on stock prices rejected.

4) Test results show that Return On Equity has a coefficient of 0.419515 and significance of $0.3018>0.05$. The results obtained show the ROE has no effect and positive on the stock price of Pharmaceutical Sub-Sector companies listed in the period 2012-2016, so it can be concluded that the hypothesis that Return on Equity positive effect on stock prices rejected.

5) Test results show that Earning Per Share has a coefficient value of 0.0004 and significance of $0.001<0.05$. The result shows that EPS has positive and significant influence to stock price of Pharmaceutical Sub-Sector listed on BEl period 2012-2016, so it can be concluded that the hypothesis which stated that Earning Per Share have positive effect on stock price is accepted.

6) F-statistic value of 8,9271 with probability of 0,000017 less than 0,05 so it can be concluded that all independent variables (Current Ratio, Debt to Equity Ratio, Total Assets Turnover, Return on Equity and 
Earning Per Share) jointly significant effect on stock prices of Pharmaceutical subsector listed on the Stock Exchange period 2012-2016.

\section{Suggestions}

Based on the conclusions in the discussion, the authors provide the following suggestions :

1) For Pharmaceutical Sub-Sector companies need to improve financial performance in order to increase stock price.

2) Investors and prospective investors can consider the Earning Per Share, from Pharmaceutical Sub-Sector Companies as the main factor before investing, because the ratio in this research proved to have a significant effect on Stock Price.

3) For the next researcher who will examine about similar problems with this research to reduce all the limitations that are as follows:

a. Researchers only use some financial ratios: liquidity ratio, solvency ratio, activity ratio, profitability ratio, and market ratio are described with indicators of Current Ratio, Debt to Equity Ratio, Total Assets Turn Over, Return on Equity, and Earning Per Share.

b. Researchers only take samples of 8 companies selected samples conducted by purposive sampling method.

c. Researchers only use data for 5 years.

With the above limitations, then to obtain better results researcher further suggested other researcher:

1) Researchers can use all the variables contained in financial ratios, with a more complete indicator so as to represent and support subsequent research.

2) Researchers are advised to add other factors such as macro conditions such as interest rates, inflation rate, foreign exchange rates, political and social situation and so forth
3) Researchers should add more years, in order to know the problem more clearly and strengthen previous studies.

\section{BIBLIOGRAPHY}

\section{Books:}

Tracy, Axel. (2012). Ratio Analysis Fundamental. Sidney : RA.net

Mehta, B.K.. (2016). Cost and Management Accounting. Agra Martura : SBPD Publication.

Baker, Kent, H \& Powell Gary. (2009). Understanding Financial Management. Australia : Blackwell.

Brigham, Eugene \& Joel F Houston (2010). Dasar-dasar Manajemen Keuangan Buku 1, Edisi Kesebelas. Jakarta : Salemba Empat.

Hieghter, Dan L., Maryanne M. Mowen, and Don R, Hansen. (2008). Fundamental Cornerstones of Managerial Accounting. USA : Thomson Heigher Education.

Asmirantho, Edhi. (2013). Financial Management .Learning Books, Pakuan University.

Shim, Jae K., Ph. D. \& Joel G. Siegel, Ph. D., CPA. (2007). Handbook of Financial Anlysis Forecasting, and Modeling. Chicago :Printed in the United States of America.

Wahlen, James M., Stephen Baginski, Mark Bradshaw. (2017). Financial Reporting, Financial Statement Analysis, And Valuation. Boston : Cengage Learning, inc.

Khan, MY and P K Jain (2012). Financial Management. New Delhi. India : Mc. Graw-Hill.

Norman H. Godwin \& C. Wayne Alderman. (2010). Financial Accounting. Boston : Cengage Learning.

Mc.Lean, Robert. (2003). Financial Management. United States of America : Delmar.

Van Horne, J, \& John Wachowicz, J. (2009). Financial Management Prinsip-Prinsip Manajemen Keuangan.Edisi 13, 
Penerjemah Quratul'ain Mubarakah, Jakarta : Salemba Empat.

\section{Journal :}

Hutapea, Albertha, Ivone Saerang, Joy Tulung (2017). Pengaruh ROA, NPM, DER, dan TATO terhadap harga saham industri otomotif dan komponen yang terdaftar di BEl. Journal EMBA Vol.5 no.2 2017 ISSN 2303-1174

Asnita (2013). Pengaruh Kinerja Keuangan Terhadap Harga Saham Pada Industri Farmasi di BEI Periode 2008-2010. Jurnal Dinamika Manajemen Vol. 1, No. 2 AprilJuni 2013 ISSN : 2338-123x

Sudarsono, Bambang \& Bambang sudiyatno (2016), Faktor-Faktor yang Mempengaruhi Return Saham pada Perusahaan Property dan Real Estate yang terdaftar pada Bursa Efek Indonesia Tahun 2009-2014. Jurnal Bisnis dan Ekonomi (JBE) Maret 2016, Hal 30-51 ISSN: 1412-3126. Vol. 23 No1

Artha, Danika Reka, Noer Azam Achsani, Hendro Sasongko (2014), Analisis Fundamental Teknikal dan Macroekonomi Harga Saham Sektor Pertanian. JMK (Jurnal Manajemen dan Kewirausahaan), Institute Pertanian Bogor, Vol.16, No. 2, September 2014, Hal: 175-184 ISSN 1411-1438 print / ISSN 2338-8234 online

Asmirantho, Edhi dan Elif Yuliawati (2015). Pengaruh Dividen Per Share (DPS), Dividen Payout Ratio (DPR), Price to Book Value (PBV), Debt to Equity Ratio (DER), Net Profit Margin (NPM), dan Return On Asset (ROA) terhadap Harga Saham pada Perusahaan Manufaktur Sub Sektor Makanan dan Minuman dalam Kemasan yang Terdaftar di BEI.Jurnal IImiah Akuntansi Fakultas Ekonomi, E-ISSN 2502-4159

Wati, I Gusti Ayu Purnama (2015), The Influence of Coorporate Characteristic and Fundamental Makro Economy Factor of Automotive Company Stock Price on Indonesian Stock Exchange.
International Journal of Bussines, Economic and Law, Vol. 6, Issue 1 (Apr) 2015, ISSN 2289-1552.

Johannes, and Meri Arisandi (2013), Pengaruh ROA, DER, CR, Inflasi, danKursTerhadap Return Saham (Studi Kasus Industri Makanan dan Minuman yang Terdaftar di BEI Periode 2008-2012). Jurnal Dinamika Manajemen Vol. 1, No. 4 Oktober-Desember 2013. ISSN: 2338$123 \mathrm{X}$

Komala, Lievia Angela Pinkan, Paskah Ika Nugroho (2013), The Effects of Profitability Ratio, Liquidity, and Debt towards Investment Return. Journal of Business and Economics. USA November 2013, Volume 4, No. 11 ISSN 2155-7950

Menike M. G. D. \& U. S. Prabath (2014), The Impact of Accounting Variabels on Stock Price: Evidence From the Colombo Stock Exchange, Srti Lanka. International Journal of Bussiness and Management; Vol. 9, No. 5, 2014. ISSN 1833-3850, EISSN 1833-8119. Published by Canadian Center of Science and Education

Kodithuwakku, Ms. Sujeewa (2016), Impact of Firm Specific Factors on The Stock Prices: A Case Study on Listed Manufacturing Companies in Colombo Stock Exchange. International Journal for Research in Business, Management and Accounting, Vol 2, Issue 3, March 2016. ISSN: 24556114.

Dewi, Putu Dina Aristya, I.G.N.A. Suaryana (2013), Pengaruh EPS, DER, dan PBV terhadap Harga Saham. E-Jurnal Akuntansi, Universitas Udayana, Vol. 4, No. 1 ISSN: 2302-8556.

Valintino, Reynard dan Lana Sularto (2013). Pengaruh Return On Asset (ROA), Current Ratio (CR), Return On Equity (ROE), Debt to Equity Ratio (DER), dan Earning Per Share (EPS) Terhadap Harga Saham Perusahaan Manufaktur Sektor Industri Barang Konsumsi di BEI.Jurnal Proceeding PESAT (Psikologi, Ekonomi, Sastra, Arsitektur dan Teknik Sipil). Oktober 2013. ISSN : 1858-2559 
Baghazadeh, Reza dan Mahboobeh Roohi (2013). Relationship Between Current Ration and Stock Price- a study on NSE India (2009-2012). International jurnal of Math Sciences Vo.3 no.1 Jan-jun 2013 ISSN 2230-9888

Gupta, Sheenu (2016), Fundamental Factors Affecting Stock Prices of Vardgman Textiles Limited.Chandigarh University, Mohali, India. GE-International Journal of Management Research, Vol.4, No 6,June 2016.

Murniati, Siti (2016), Effect of Capital Structure, Company size and Profitability on the Stock Price of Food and Beverage Companies Listed on the Indonesia Stock Exchange. Information Maanagement and Bussiness Review Universitas Indonesia. Vol. 8, No. 1, February 2016, ISSN 220-3796.

Syamsurijal Tan, Agus Syarif dan Delfira Ariza (2014). Analisis Faktor-Faktor yang Mempengaruhi Harga Saham pada
Industri Transportation Service di Bursa Efek Indonesia Tahun 2009-2012. Dinamika Manajemen Vol.2 No.2. AprilJuni 2014. ISSN : 2338-123X.

Manopo, Vera Ch, Benhard Tewal, Arrazi Bin Hasan Jan (2017). The Effect of $C R, D E R$, $R O A$, And NPM on stock price foods and beverages listed in BEI 2013-2015. Journal EMBA vol. 5 no.3 Juni 2017 ISSN : 2302-1174.

\section{Website :}

(www.idx.co.id).

(www.sahamok.com).

(www.kemenperin.go.id).

(www.detik.finance.com).

(March 22, 2017 - 12:32 pm, Business Economy Column).

(www.cnnindonesia.com).

(January 9, 2017 - 9:20 pm, Economic Column)

(www.mediaindonesia.com).

(March 17, 2017 - 10:25 pm, Economic

Column) 